\section{Trends in breastfeeding research by Brazilian nurses}

\section{Evolução da pesquisa em aleitamento materno conduzida pela enfermagem brasileira}

Departamento
de Enfermagem,
Universidade Federal do
Ceará, Fortaleza, Brazil.
2 School of Nursing,
University of Virginia
Health Systems,
Charlottesville, U.S.A.
Correspondence
D. F. Glick
School of Nursing, University
of Virginia Health Systems.
P.O. Box 800782,
Charlottesville, VA,
22908, U.S.A.
dfg6x@virginia.edu

\section{Abstract}

Exclusive breastfeeding is acknowledged as important for survival, optimal growth, and development of infants. The current review presents a synthesis of research output by Brazilian nurses on breastfeeding over the last 20 years, analyzes the theoretical and methodological issues emerging from studies on breastfeeding in Brazil, and provides directions for future research and practice by nurses in the area breastfeeding. Studies included in this review were identified through LILACS searches of Portuguese-language sources. Articles were organized and analyzed chronologically by comparing the evolution of the Brazilian Breastfeeding Program. The incomplete research output of the Brazilian nursing profession in regard to breastfeeding research needs to be addressed. In addition, specific cultural, sociological, and anthropological characteristics of Brazilian regional settings remain to be explored. Emphasis on potential confounders and critical interrelations is warranted.

Breastfeeding; Nursing; Nursing Research
Mônica Oliveira B. Oriá 1

Doris F. Glick 2

Maria Dalva S. Alves 1

\section{Introduction}

Exclusive breastfeeding is acknowledged as important for survival, optimal growth and development of infants in low-income countries 1 . Numerous investigators have reported a relationship between breastfeeding and infant health. Such authors reveal that breastfed infants experience lower rates of acute and chronic otitis media 2 , bronchiolitis 3 , diarrhea 4 , meningitis 5 , and necrotizing enterocolitis 6 , suffer less recurrent wheezing 7 , have higher mean IQs 8 , and develop insulin-dependent diabetes mellitus less frequently 9 than those who are bottle-fed.

Breastfeeding can also be beneficial to the mother's health by reducing the risk of ovarian cancer and bone demineralization in comparison to mothers who do not breastfeed their infants 10 . Women who breastfeed are less likely to develop osteoporosis and breast cancer 11,12,13 and are more prone to better social interactions 14 . Therefore, exclusive breastfeeding has been strongly recommended during the first six months of the infant's life, continued by mixed nutrition until twelve months, according to World Health Organization (WHO) recommendations. Indeed, in developing countries, breastfeeding has proved to be an efficient strategy to improve child health and to prevent diseases in adulthood.

Over the last 20 years, Brazilian health policy has encouraged breastfeeding programs in 
an effort to prevent early childhood illnesses and to reduce infant mortality rates (IMR). For two decades, breastfeeding campaigns have successfully enhanced people's commitment to health promotion on a large scale.

The Brazilian nursing profession has played an important role in encouraging health interventions in lactating mothers as a strategy to improve exclusive breastfeeding rates and to decrease early weaning. However, the real impact of interventions by nursing teams in preventing early weaning and overall infant illnesses in Brazil is not well understood. The current review presents a synthesis of research output by Brazilian nurses on breastfeeding over the last 20 years, analyzes the theoretical and methodological issues emerging from studies on breastfeeding in Brazil, and provides directions for future nursing research and practice regarding breastfeeding promotion.

\section{Methods}

The studies included in this review were identified through LILACS (Latin American and Caribbean Health Sciences Literature) searches of Portuguese-language sources published since 1983, by using the following key words: breastfeeding (aleitamento) and nursing (enfermagem); breastfeeding, nursing, and Brazil. We chose the LILACS Database because it has been the primary source of indexation for Latin American journals. Further sources (97 references) were located by cross-referencing, but this review includes only papers published in Brazilian nursing journals by Brazilian nurses. We excluded papers published in Brazilian and international nursing journals that were written in other countries and/or written by other professionals. Books, book chapters, theses, and dissertations were also excluded because of the difficulty in organizing these materials for a review. Abstracts were excluded based on insufficient information to be analyzed. Articles were organized and analyzed chronologically by comparing the evolution of the Brazilian Breastfeeding Program (BBP). A comprehensive review and implications for future research and practices in breastfeeding by the nursing profession are presented.

\section{Results}

The literature searches identified 39 papers published in the eight main Brazilian nursing journals: Acta Paulista de Enfermagem, Cogitare Enfermagem, Revista Brasileira de Enfermagem, Revista Gaúcha de Enfermagem, Revista Latino-americana de Enfermagem, REME - Revista Mineira de Enfermagem, Revista da Escola de Enfermagem da USP, and Texto \& Contexto-Enfermagem. We identified the number of published papers according to the publication date (Table 1). Among these papers, the authors used different study designs, as demonstrated in Table 2. However, for this review we considered only research articles (Table 3 ). While we were organizing articles by area, we recognized that most research output was from Southeast Brazil $(n=15)$. We found no articles written in North or Central-West Brazil. In order to improve the understanding of historical trends in nursing research, we did compar-

Table 1

Number of articles on breastfeeding published

by nurses in Brazil, according to publication date.

\begin{tabular}{lrr}
\hline Date & N & \multicolumn{1}{c}{$\%$} \\
\hline $1983-1987$ & 4 & 10.3 \\
$1988-1992$ & 6 & 15.3 \\
$1993-1997$ & 8 & 20.5 \\
$1998-2002$ & 21 & 53.9 \\
Total & 39 & 100.0 \\
\hline
\end{tabular}

Table 2

Study designs in articles on breastfeeding

by authors in Brazilian nursing journals, 1983-2002.

\begin{tabular}{lrr}
\hline Design & N & \% \\
\hline Reflection & 1 & 2.6 \\
Review & 4 & 10.3 \\
Report of experience & 6 & 15.4 \\
Update & 7 & 17.9 \\
Survey & 21 & 53.8 \\
Total & 39 & 100.0 \\
\hline
\end{tabular}


Table 3

Characteristics and distribution of articles on breastfeeding published in Brazilian nursing journals, $1983-2002$.

\begin{tabular}{|c|c|c|c|c|c|c|}
\hline & Study & Location & $\begin{array}{l}\text { Subject } \\
\text { characteristics }\end{array}$ & Type of study & $\begin{array}{l}\text { Theoretical } \\
\text { framework }\end{array}$ & Research tools \\
\hline 1 & Fadul \& Xavier 16 & Ribeirão Preto (SE) & 60 mothers & $\begin{array}{l}\text { Exploratory } \\
\text { (prospective) }\end{array}$ & & Interview \\
\hline 2 & Vale \& Albuquerque 17 & Fortaleza (NE) & 10 mothers & $\begin{array}{l}\text { Exploratory } \\
\text { (prospective) }\end{array}$ & & Interview \\
\hline 3 & Scochi et al. 18 & Ribeirão Preto (SE) & 76 puerperae & $\begin{array}{l}\text { Exploratory } \\
\text { (prospective) }\end{array}$ & & Structured interview \\
\hline 4 & Silva 19 & São Paulo (SE) & 25 puerperae & $\begin{array}{l}\text { Quasi-experimental } \\
\text { (prospective) }\end{array}$ & & $\begin{array}{l}\text { Medical records and } \\
\text { structured interview }\end{array}$ \\
\hline 5 & Scochi et al. 20 & Ribeirão Preto (SE) & 92 puerperae & $\begin{array}{l}\text { Descriptive } \\
\text { (prospective) }\end{array}$ & & Structured interview \\
\hline 6 & Marcon 22 & Maringá (S) & 60 mothers & $\begin{array}{l}\text { Exploratory } \\
\text { (prospective) }\end{array}$ & Ground theory & Participant observation \\
\hline 7 & Almeida 23 & Salvador (NE) & 36 mothers & $\begin{array}{l}\text { Qualitative } \\
\text { (prospective) }\end{array}$ & $\begin{array}{l}\text { Historical } \\
\text { materialism }\end{array}$ & Semi-structured interview \\
\hline 8 & Abrao et al. 24 & São Paulo (SE) & $\begin{array}{l}12 \text { puerperae } \\
\text { (post-cesarean) }\end{array}$ & $\begin{array}{l}\text { Descriptive } \\
\text { (prospective) }\end{array}$ & & $\begin{array}{l}\text { Nursing consultation using } \\
\text { research forms }\end{array}$ \\
\hline 9 & Boehs 25 & Florianópolis (S) & 46 mothers & $\begin{array}{l}\text { Exploratory } \\
\text { (prospective) }\end{array}$ & & Questionnaire \\
\hline 10 & Pereira et al. 26 & Ribeirão Preto (SE) & 10 nurses & $\begin{array}{l}\text { Qualitative } \\
\text { (prospective) }\end{array}$ & & Semi-structured interview \\
\hline 11 & Silva 27 & Ribeirão Preto (SE) & 42 nursing students & $\begin{array}{l}\text { Qualitative } \\
\text { (prospective) }\end{array}$ & $\begin{array}{l}\text { Symbolic } \\
\text { interactionism }\end{array}$ & $\begin{array}{l}\text { Participant observation } \\
\text { and interview }\end{array}$ \\
\hline 12 & Harada et al. 28 & São Paulo (SE) & $\begin{array}{l}66 \text { mothers whose } \\
\text { infants were hospitalized }\end{array}$ & $\begin{array}{l}\text { Cross-sectional } \\
\text { (prospective) }\end{array}$ & & Interview \\
\hline 13 & $\begin{array}{l}\text { Grazziotin \& } \\
\text { Yamasaki } 29\end{array}$ & Curitiba (S) & 300 mother-infant pairs & $\begin{array}{l}\text { Quasi-experimental } \\
\text { (prospective) }\end{array}$ & & $\begin{array}{l}\text { Nursing consultation and } \\
\text { infant physical exam }\end{array}$ \\
\hline 14 & $\begin{array}{l}\text { Pinelli \& } \\
\text { Friedlander } 30\end{array}$ & São Paulo (SE) & 130 first-time mothers & $\begin{array}{l}\text { Randomized } \\
\text { (prospective) }\end{array}$ & Andragogy & Structured interview \\
\hline 15 & Rozario \& Zagonel 31 & Curitiba (S) & 15 mothers & $\begin{array}{l}\text { Descriptive } \\
\text { (prospective) }\end{array}$ & $\begin{array}{l}\text { Philosophy and } \\
\text { science of caring }\end{array}$ & $\begin{array}{l}\text { Educative seminars, nursing } \\
\text { history and interview }\end{array}$ \\
\hline 16 & Machado et al. 32 & Ribeirão Preto (SE) & 22 mothers & $\begin{array}{l}\text { Qualitative } \\
\text { (prospective) }\end{array}$ & & Semi-structured interview \\
\hline 17 & Nakano \& Mamede 33 & Ribeirão Preto (SE) & 20 mothers & $\begin{array}{l}\text { Qualitative } \\
\text { (prospective) }\end{array}$ & Feminist theory & Semi-structured interview \\
\hline 18 & Nakano \& Mamede 34 & Ribeirão Preto (SE) & 22 mothers & $\begin{array}{l}\text { Qualitative } \\
\text { (prospective) }\end{array}$ & & Semi-structured interview \\
\hline 19 & Ichisato \& Shimo 35 & Ribeirão Preto (SE) & $\begin{array}{l}3 \text { women of the } \\
\text { same family }\end{array}$ & $\begin{array}{l}\text { Case study } \\
\text { (retrospective) }\end{array}$ & & Semi-structured interview \\
\hline 20 & Oscar et al. 36 & Belo Horizonte (SE) & 6 puerperae & $\begin{array}{l}\text { Qualitative } \\
\text { (prospective) }\end{array}$ & Phenomenology & Interview \\
\hline 21 & Abrao et al. 37 & São Paulo (SE) & 181 mother-infant pairs & $\begin{array}{l}\text { Descriptive } \\
\text { and analytic } \\
\text { (prospective) }\end{array}$ & & $\begin{array}{l}\text { Interviews with mothers } \\
\text { and physical examination } \\
\text { of infants. }\end{array}$ \\
\hline
\end{tabular}

Regions of Brazil: NE = Northeast; $\mathrm{S}=$ South; SE $=$ Southeast.

isons within the BBP timeframe, organizing our data according to time windows.

\section{First period: 1983-1987}

The BBP was launched in March 1981 through a mass media campaign by television, radio, and print media advertising, reaching 20 mil- lion households nationwide 15. However, the first paper published by nurses in breastfeeding research emerged in 1983 with a study by Fadul \& Xavier 16 and the second in 1986 with Vale \& Albuquerque 17 . Both papers focused on weaning. These authors aimed to understand why mothers weaned their babies early. Fadul \& Xavier 16 observed that $42(70.0 \%)$ of mothers weaned their babies before three months. Para- 
doxically, mothers with more schooling weaned even earlier, as follows: illiterate mothers, 4 (6.6\%); mothers with complete high school, 17 $(28.5 \%)$. In addition, urban women $(n=38$, $63.3 \%$ ) were more likely to wean their babies before three months as compared to rural mothers $(n=4,6.6 \%)$.

According to Vale \& Albuquerque 17 the main causes of early weaning were: (1) pediatrician's advice to use formula milk; (2) suppression of breastmilk because of fear; (3) "lumping" of milk attributed to the baby's burping during breastfeeding; (4) contraceptive use; (5) concern about the breasts' appearance; (6) mother's concern about the possibility of acquiring illnesses due to calorie loss; and (7) prioritizing domestic tasks.

Based on their findings, Vale \& Albuquerque 17 strongly recommended reinforcing attitudes toward breastfeeding during prenatal and pediatric consultations (especially in the first six months postpartum), in order to further encourage women's adherance to exclusive breastfeeding practices for a much longer period.

\section{Second period: 1988-1992}

In 1988, four new policies in favor of breastfeeding practices were consolidated in Brazil, representing a historical turning point in the program: (1) the National Ruling on Commercialization of Infant Foods; (2) Ruling on Human Breast Milk Banks; (3) inclusion of the right to a four-month maternity leave in the Brazilian Constitution; (4) inclusion of the right to a five-day paternity leave in the Brazilian Constitution.

During this critical period of establishing and maintaining the first program goals, nurses began playing a more active role in the new BBP, as shown by three articles on breastfeeding 18,19,20. These studies used different designs and focused on different themes (feeding regimens, breast engorgement, and mother's knowledge about breastfeeding). Nevertheless, the general focus was on women's health, revealing the awareness of Brazilian nurses concerning women as important promoters and recipients of health care during the lactation process.

According to Scochi et al. $18,85.53 \%(n=65)$ of mothers interviewed offered breast milk on a self-demand scheme, and $91.1 \%$ of their decisions about breastfeeding practices were in accordance with proper technical procedures. Among 11 (14.47\%) mothers who chose to breastfeed according to a rigid schedule, $33.0 \%$ justified their choice based on a hospital routine in which a baby is fed every three hours. While hospital routines are conducted to optimize the work in the hospital environment, they may not always work in the home context. Some mothers learned and replicated these practices at home because they believed that this model was better for feeding their babies.

Silva 19 tested a systematized procedure of nursing care for mothers with breast engorgement. The intervention represented a combination of three different techniques: massage with an electric vibrator, suckling stimulus for the baby, and hand manuevers for the mammary glands. The combination of these techniques was termed the "Systematic Nursing Care Procedure", applied after each feed until the engorgement regressed. According to her findings, therapeutic sessions were 4.4 times more common in women with glandular breast engorgement and resulted in a reduction in total breast engorgement after an average of 6 hours and 54 minutes for the lobar type and 11 hours for glandular breast engorgement. Regression time was longer in women with low birth weight babies and in those whose babies remained less time suckling. Nursing intervention was efficient by decreasing symptoms of breast engorgement, preventing cracked nipples, and avoiding other common complications related to breast engorgement, in addition to promoting women's self-care during treatment.

In another study of 92 women by Scochi et al. 20,73 mothers $(79.34 \%)$ were assisted at prenatal care units. Of these, 65 (89.04\%) did not receive any nursing assistance related to infant care. Among the themes chosen by the researchers to evaluate educational programs, care with the umbilical cord stump was preferred by the women in the study, reaching a higher learning index than other items measured at hospital admission and discharge. In addition, primiparous mothers showed more positive attitudes towards technical aspects of infant care. All mothers in the study showed willingness to breastfeed, as evaluated at both admission and discharge. However, a possible bias is that the women might be more prone to breastfeed by convenience during hospitalization, fearing retaliation from the health care team and failing to disclose their real decisions about intended breastfeeding practices. In addition, the study was not extended to the home level, so women's knowledge and breastfeeding practices outside the hospital remained insufficiently explained. Moreover, the time elapsed between admission for normal delivery or ce- 
sarean and hospital discharge may not be sufficient to evaluate real behavioral changes in a family context.

\section{Third period: 1993-1997}

In 1992, the implementation of the "BabyFriendly Hospital Initiative" in Brazil enhanced previous goals to fulfill "ten steps to successful breastfeeding" by highlighting the natural advantages of breast milk and not encouraging use of milk substitutes. Several hospitals were enrolled in this program. However, in 1996 the Brazilian Ministry of Health decided to add further requirements for enrollment, especially focused on lowering cesarean rates and thus substantially impacting new enrollments in this program 21. During this period, four new studies were published by Brazilian nurses 22,23,24,25.

The study by Marcon 22 highlighted the process, concepts, and women's experiences during weaning. Study participants unexpectedly supported an age limit for breastfeeding ( $\cong 1$ year old). After this age, they believed that breast milk would no longer provide adequate nutrition. In addition, they were strongly influenced by their social groups toward weaning practices, contributing to the high weaning rates in this population.

A second study by Almeida 23 addressed women's emotions during the process of early weaning. Data revealed that breastfeeding was a dynamic social practice, constantly in reconstruction, with continous shaping and remodeling. Breastfeeding and weaning were intermingled with myths, misconceptions, and prejudices based on historical and sociological backgrounds. Women's emotions during breastfeeding and weaning were shown to be related to historical momentum and ongoing educational processes. When guilt was identified as an emotional component of the weaning process, the women began finding excuses to justify their weaning decision and redeem themselves. The author found several meanings underlying the weaning response, including indifference, sacrifice, guilt, pleasure, relief, and exploitation.

The third study, by Abrao et al. 24, designed a model for data collection to validate the NANDA-I (North American Nursing Diagnosis Association, Taxonomy I) generally used as a dignostic tool in breastfeeding practices. Informants were provided with nursing couseling on the 7 th and 15th days after delivery. The authors found that among 25 nursing diagnoses from the instrument, only $13(52.0 \%)$ were clearly identified in this population, justifying the need to reevaluate the tool. However, the sample was limited to post-cesarean women and thus did not consider the needs of women who had experienced vaginal delivery. In addition, the sample was too small $(n=12)$ for more conclusive findings and was thus inappropriate to suggest replacing the NANDA tool in regard to breastfeeding.

The last study in this period was published by Boehs et al. 25, who analyzed the breastfeeding experience up to the 6th month after birth using interviews with mothers at 15 days and 2, 4, and 6 months after delivery. These researchers found that $41.3 \%(n=19)$ of the mothers breastfed their babies at the 6th month, but only $15.2 \%(n=7)$ exclusively breastfed. In the first interview, $26.0 \%(n=12)$ had introduced other foods into the baby's diet. Causes of low exclusive breastfeeding rates were grouped as follows: (1) mothers who were unable to breastfeed; (2) infants who were incapable of being breastfed; (3) mother's beliefs; (4) the pediatrician's orientation; and (5) family influence.

Such findings highlight the importance of contextual and cultural factors in the decisionmaking process on breastfeeding and the family's key role in supporting and influencing a mother's decisions. Educational programs targeting these factors are critically important. Difficulties in breastfeeding were more frequent in the first interview (15th day after delivery). By experiencing breastfeeding for the first time and after receiving adequate counseling from researchers about how to deal with common problems, mothers had become more confident and were more prone to sustain breastfeeding.

\section{Fourth period: $1998-2002$}

Since 1999, the Ministry of Health has implemented new policies regarding milk formula, pacifiers and baby bottles for companies, which are contradictory to the National Ruling on Commercialization of Infant Foods. In 20002001 the ruling was reviewed, extended, and elaborated in greater detail 21.

We identified 12 articles published during this period, two of which focused on breastfeeding 26,27 . Silva 27 conducted a prospective study to evaluate breastfeeding representation for nursing students in order to understand their conceptions concerning care for the mother-infant pair during the lactation process. According to nursing students, the most important meaning was "be there with the mother", to support and counsel mothers, an approach 
they felt would result in increased breastfeeding rates. Thus, from the student's perspective, nursing care was considered more than just a technical issue.

Pereira et al. 26 studied the relationship between the health model implemented under the Unified National Health System (SUS) and current practices in a primary care center. Nurses reported some operational difficulties due to disagreements between the nurses' (holistic) and physicians' (segmented) approaches. Nurses in the study by Pereira et al. reported that breastfeeding practices should not be separated from the health policy context, and therefore breastfeeding promotion strategies should address local needs, underpinned by professional availability, investment in human resources, and periodic and systematic assessment of outcomes.

Harada et al. 28 aimed to identify factors associated with early weaning and mixed nutrition (breast milk + other milks or teas) in hospitalized infants. These researchers suggested that early weaning was directly related to the mother's lower schooling. Other factors were: "insufficient milk" (44.0\%), "lack of milk" (35.0\%), and "mother's occupation" (8.0\%). The main causes of infant hospitalization were bronchopneumonia and pneumonia with or without complications (71.2\%) and diarrhea (27.3\%).

During the review, we identified only one study focusing on premature newborns 29 , highlighting nursing care in human breast milk banks (HBMB), a practice which has played a significant role in increasing weight gain in premature newborns after hospital discharge. This study followed 300 infants every 72 hours until they began gaining weight $(18 \mathrm{~g} /$ day or $125 \mathrm{~g} /$ week). In the first assessment, only 33 (11.0\%) infants showed higher weight than before hospital discharge. However, other infants enrolled in this study exhibited insufficient weight gain $(24.0 \%)$ and even weight loss (65.0\%). Nursing care in HBMBs during the second assessment was critical for improved weight gain in that group, with only $5.1 \%$ presenting weight loss. Among premature infants showing weight loss or insufficient gain, several factors were associated with these outcomes, including cultural influences, specifically taboos and beliefs such as "weak milk" and "small amount of milk". In addition, the authors reported other important factors such as the need to complement the infant's diet with water and tea, uncertainty about breast milk quality, incorrect breast maneuvers during suckling, stress, inadequate management of the breast before, during, and after breastfeeding, and insufficient sleep. The data emphasized the importance of regular follow-up of mother-infant pairs to encourage successful breastfeeding and promote the health of premature infants.

Concerned with education for first-time mothers, Pinelli \& Friedlander 30 developed an educational program based on an andragogy model, highlighting two main themes: "breastfeeding and breast care" and "newborn infant care". Healthier babies and fewer maternal complications were seen in the group of women who had chosen educational programs as compared to the other group that was enrolled in educational activities arbitrarily chosen by nurses. The authors highlight the need for targeted programs, including themes previously designed to meet the client's own needs. According to these findings, women should decide what and how much they need to learn. Such a personalized group approach would require that nurses have a wider range of technical and specialized training on breastfeeding issues, learning and teaching skills to assess individual needs.

Rozario \& Zagonel 31 implemented interactive activities in hospital rooming-in by utilizing an educational approach. They have suggested more effective actions by identifying the mother's own needs in regard to breastfeeding, and consequently providing more personalized and more meaningful holistic care.

In a series of three publications, Nakano and colleagues discuss issues in the decisionmaking process, breastfeeding practices, and women's right to breastfeed $32,33,34$. The authors studied breastfeeding practices from a female perspective and suggested that breastfeeding represents a feminine prototype to socially qualify for women's role in society 33 . In addition, according to these researchers, women suffer from ambivalence between self-adjustment (obligation, giving, and sacrifice) and resistance (physiological inability to breastfeed). This conflict causes more distress and frustration due to their inability to sustain "a model of idealized motherhood" required by the social group.

Machado et al. 32 identify three important components in the decision-making process on breastfeeding: family, health professionals, and the media. In regard to family issues, these researchers found a beneficial role in the husband/father. Family factors can positively influence the decision-making process on breastfeeding. In regard to professional care, a major concern was the importance of appropriate maneuvering to breastfeed, revealing a preference for a biological approach in nursing. In addition, these authors emphasize the advantages of technical education to encourage lac- 
tating woman. Lastly, the media was important for women's understanding of the advantages of breast milk.

In the last study of the series, Nakano \& Mamede 34 analyzed the social environment in which Brazilian women are immersed during breastfeeding, focusing on female employees. The authors highlight a Brazilian national law granting a 120-day leave for women to breastfeed at home. They explored the model's feasibility, which does not currently cover women in the informal labor market, apart from the law's benefits. In addition, even for women who are likely to be granted these 120 days at home, at the end of the breastfeeding leave they are unable to continue breastfeeding because of the scarcity of daycare centers near their places of work. In turn, this 120-day employment leave to breastfeed changes women's behavior and promotes a more flexible role as spouse, mother, and employee, whereby women tend towards household and spousal roles, declining to play a productive role in society. This restriction to household life can have a tremendously negative impact on family income, besides increased dependency on the husband. These researchers identified the importance of nursing care to promote breastfeeding, not only biologically, but also in assisting women within their historical social context.

Ichisato \& Schimo 35 conducted a study with three women from the same family in different generations (mother/daughter/granddaughter) in order to analyze feeding traditions during breastfeeding. These investigators highlighted that breastfeeding is not only a biological issue, but also historical, sociological, and psychological. It can be heavily influenced by culture, beliefs, and philosophical conceptions, which in turn can take the form of a socio-cultural legacy elaborated through distinct family meanings in the woman's world. This behavior was clearly evidenced when mothers started using milk secretion stimulants (from regional galactogogue sources), which were mainly chosen through mother-to-daughter communication in situations of hypogalactia. The women usually try a variety of fruits, juices, fish, poultry, milk, cheese, tea, and chicken soup of dubious pharmacological benefit before seeking professional aid.

Oscar et al. 36 conducted a qualitative study on meanings ascribed by lactating women after breastfeeding counseling. These authors identified that nursing counseling helped to foster behaviors involving comfort and confidence during breastfeeding and better relationships between mother-child pairs by strength- ening bonds and creating opportunities for self-expression and questioning. Based on these findings, the authors suggest a complete nursing follow-up at least during the first steps of breastfeeding. This nursing support aims to avoid frustration, difficulties, and behavioral errors which could jeopardize the early breastfeeding process and ultimately facilitate early weaning.

Abrao et al. 37 recently conducted a descriptive and analytical study enrolling 181 women to clinically validate the key characteristics of effective breastfeeding diagnosis under NANDA-I. The authors validated 5 constant characteristics: (1) the child's ability to find the nipple and areola; (2) signs and/or symptoms of oxytocin release; (3) regular and sustained suckling/swallowing at the breast; (4) infant contentment after feeding; and (5) normal bowel movement patterns for age.

\section{Discussion}

Based on a historical overview of nursing research on breastfeeding practices in Brazil, we have identified growing research interest in breastfeeding outcomes related to recommendations by the Brazilian Breastfeeding Program. The research approach was based on a women's health perspective rather than a more varied point of view such as the family context or other health paradigms, including structural and operational issues and local policies. Only one article published in Brazilian nursing journals directly addressed the benefits of breastfeeding for child care 29 .

Most of the papers used a qualitative approach to examine the benefits of breastfeeding. Few studies used quantitative data to evaluate independent variables about successful breastfeeding rates. Surprisingly, no studies used more rigorous statistical analyses, such as multilinear regression models and multivariate correlations as the basis for more powerful findings. Additionally, some aspects of ecology and environmental relationships are still frequently understimated. The scarcity of quantitative research limits the portrayal of intercontextual and intracontextual relationships between different variables. The lack of studies that acknowledged potential confounding factors or employed more refined research designs underline the significant need for more rigorous research by the nursing profession on breastfeeding in Brazil.

Among the 21 articles reviewed, only seven were supported by a theoretical framework. 
Theories were diversified and sometimes broadly assessed. Importantly, no studies centered on culturally dynamic subjects by using ethnography and ethno-nursing. We emphasize the importance of the cultural approach for nursing research because of the socio-cultural peculiarities of each Brazilian region. Accordingly, it is critical to shape novel BBP strategies that are appropriate for regional circumstances in order to fulfill local health priorities.

Appropriate health information is especially important for primigravid women and mothers who have experienced previous problems with breastfeeding. It has been shown that highlighting the advantages of breastfeeding for the child and mother and providing technical and material support for breast preparation is not sufficient to successfully increase breastfeeding rates. Women need to receive special nursing assistance and appropriate cultural care in local communities in order to interrupt an unhealthy behavioral cycle and define new health attitudes and concepts. Brazilian nurses

\section{Resumo}

Sabe-se que o aleitamento materno exclusivo é importante para a sobrevivência, crescimento e desenvolvimento infantil. Os objetivos desta revisão foram: apresentar uma síntese da produção intelectual da enfermagem brasileira na área do aleitamento materno nos últimos vinte anos, criticar questões teóricas e metodológicas dos estudos, e providenciar direções para futuras pesquisas e práticas de enfermagem em relação ao aleitamento materno. Os estudos incluídos nesta revisão foram identificados por meio de busca no LILACS para estudos publicados em português. Os artigos foram organizados e analisados cronologicamente, traçando uma comparação com a evolução do Programa Nacional de Aleitamento Materno. A lacuna da pesquisa em aleitamento materno pela enfermagem brasileira precisa ser preenchida como uma agenda prioritária. Além disso, as peculiaridades culturais, sociológicas e antropológicas que caracterizam cada região brasileira precisam ser exploradas. A ênfase em potenciais co-fatores e suas inter-relações críticas precisa ser melhor explorada.

Aleitamento Materno; Enfermagem; Pesquisa em Enfermagem

\section{Contributors}

The authors all contributed equally to the preparation of this manuscript. can actively encourage breastfeeding practices by being more accessible to local communities and offering technical and emotional support for new mothers. Nurses can identify the cultural and family issues related to prevalent behaviors.

In short, we found a lack of consistent nursing data from the North and Northeast regions of Brazil. Peculiar cultural, sociological, and anthropological characteristics of Brazilian regional settings remain to be explored. Emphasis on potential confounders and critical interrelationships will enhance the validity of research outcomes. The lack of continued studies in the nursing field has resulted in a knowledge gap in theoretical and nursing practices in various areas, especially those with the greatest needs. The unfinished task of the Brazilian nursing profession in regard to breastfeeding research needs to be addressed urgently in order to creatively and efficiently gather and manage relevant public health data aimed at planning appropriate intervention strategies.

\section{References}

1. Ashraf RN, Jalil F, Khan SR, Zaman S, Karlberg J, Lindblad BS, et al. Early child health in Lahore, Pakistan: V. Feeding patterns. Acta Paediatr Suppl 1993; 82 Suppl 390:47-61.

2. Aniansson G, Alm B, Andersson B, Hakansson A Larsson P, Nylen $\mathrm{O}$, et al. A prospective cohort study on breast-feeding and otitis media in Swedish infants. Pediatr Infect Dis J 1994; 13:183-8.

3. Albernaz EP, Menezes AM, Cesar JA, Victora CG, Barros FC, Halpern R. Risk factors associated with hospitalization for bronchiolitis in the post-neonatal period. Rev Saúde Pública 2003; 37:485-93.

4. Howie PW, Forsyth JS, Ogston SA, Clark A, Florey $\mathrm{CD}$. Protective effect of breast feeding against infection. BMJ 1990; 300:11-6.

5. Silfverdal SA, Bodin L, Ulanova M, Hahn-Zoric M, Hanson LA, Olcen P. Long term enhancement of the IgG2 antibody response to Haemophilus influenzae type $\mathrm{b}$ by breast-feeding. Pediatr Infect Dis J 2002; 21:816-21.

6. Kosloske AM. Breast milk decreases the risk of neonatal necrotizing enterocolitis. Adv Nutr Res $2001 ; 10: 123-37$.

7. Chulada PC, Arbes Jr. SJ, Dunson D, Zeldin DC. Breast-feeding and the prevalence of asthma and wheeze in children: analyses from the Third National Health and Nutrition Examination Survey, 1988-1994. J Allergy Clin Immunol 2003; 111:32836.

8. Smith MM, Durkin M, Hinton VJ, Bellinger D, Kuhn L. Influence of breastfeeding on cognitive 
outcomes at age 6-8 years: follow-up of very low birth weight infants. Am J Epidemiol 2003; 158: 1075-82.

9. Ziegler AG, Schmid S, Huber D, Hummel M, Bonifacio E. Early infant feeding and risk of developing type 1 diabetes-associated autoantibodies. JAMA 2003; 290:1721-8.

10. Ball TM, Bennett DM. The economic impact of breastfeeding. Pediatr Clin North Am 2001; 48: 253-62.

11. Labbok MH. Health sequelae of breastfeeding for the mother. Clin Perinatol 1999; 26:491-503.

12. Abou-Dakn M, Scheele M, Strecker JR. Does breast-feeding prevent breast cancer?. Zentralbl Gynakol 2003; 125:48-52.

13. Lee SY, Kim MT, Kim SW, Song MS, Yoon SJ. Effect of lifetime lactation on breast cancer risk: a Korean women's cohort study. Int J Cancer 2003; 105:390-3.

14. Uvnas-Moberg K. Oxytocin may mediate the benefits of positive social interaction and emotions. Psychoneuroendocrinology 1998; 23:819-35.

15. Rea MF. The Brazilian National Breastfeeding Program: a success story. Int J Gynaecol Obstet 1990; 31 Suppl 1:79-82.

16. Fadul FD, Xavier LF. Fatores que contribuem para o desmame precoce. Rev Bras Enferm 1983; 36: 213-20.

17. Vale EG, Albuquerque MT. Conversando com as mães sobre amamentação: relato de experiências. Rev Bras Enferm 1986; 39:28-33.

18. Scochi CG, Vinha VHP, Lima RAG. Breastfeeding in a strict or flexible scheme: information given by mothers after delivery. Rev Gaúcha Enferm 1988; 9:77-81.

19. Silva IA. A systematized procedure for the technical nursing care of puerperae with breast engorgement. Rev Esc Enferm USP 1989; 23:51-68.

20. Scochi CG, Lima RAG, Delácio LB, Morais GR. O conhecimento de puérperas sobre o cuidado com o recém-nascido: avaliação da influência da internação em uma maternidade de um hospitalescola. Rev Bras Enferm 1992; 45:36-43.

21. Rea MF. A review of breastfeeding in Brazil and how the country has reached ten months' breastfeeding duration. Cad Saúde Pública 2003; 19 Suppl 1:S37-45.

22. Marcon SS. Experience by women about children late weaning. Rev Gaúcha Enferm 1996; 17:43-50.

23. Almeida MS. Sentimentos femininos: o significado do desmame para as mulheres. Texto \& Contexto Enfermagem 1997; 6:260-75.
24. Abrao AC, Gutierrez MR, Marin HF. Utilization of nursing diagnosis according to Nanda's classification for the systematization of nursing care in breast feeding. Rev Latinoam Enfermagem 1997; 5:49-59.

25. Boehs AE, Cardoso JL, Souza MA, Borges R. Study of a maternal breastfeeding situation in a peripheral neighborhood. Cogitare Enferm 1997; 2:3-6.

26. Pereira MJ, Assis MM, Reis MC. Health assistance model and nursing care given to women planning to breast feed. Rev Bras Enferm 1999; 52:423-36.

27. Silva IA. Constructing the meaning of breast feeding through nursing care. Rev Bras Enferm 1998; 51:217-30.

28. Harada MJCS, Peterlini MAS, Scardonelli R, Dias EC. Related factors to early weaning and complement breastfeeding in hospitalized children at a pediatric unit. Acta Paul Enfermagem 1999; 12: 27-34.

29. Grazziotin MCB, Yamasaki IS. Attendance of premature newborn babies from the breastfeeding clinicof human milk bank. Cogitare Enferm 2000; 5:66-8.

30. Pinelli FGS, Friedlander MR. Nursing in puerperium: application of a learnig model. Acta Paul Enfermagem 1998; 11:38-51.

31. Rozario PS, Zagonel IP. Proposal of care with an educational focus for breastfeeding mothers. Rev Bras Enferm 2000; 53:401-9.

32. Machado ARM, Nakano AMS, Shimo AKK. A influência de terceiros na prática do aleitamento materno. REME Rev Min Enferm 1999; 3:20-3.

33. Nakano AMS, Mamede MV. The practice of breastfeeding in a group of brazilian women: a movement of accomodation and resistence. Rev Latinoam Enfermagem 1999; 7:69-76.

34. Nakano AMS, Mamede MV. A mulher e o direito de amamentar: as condições sociais para o exercício da função. REME Rev Min Enferm 2000; 4:22-7.

35. Ichisato SM, Shimo AK. Breastfeeding and nutrition beliefs. Rev Latinoam Enfermagem 2001; 9:70-6.

36. Oscar A, Silvestre LK, Freitas MÉA, Chianca TCM. Maternal breastfeeding: the evidency of the nurse work space. REME Rev Min Enferm 2001; 5:2-6.

37. Abrao AC, Gutierrez MGR, Marin HF. Validation study of defining characteristics for nursing diagnosis "effective breastfeeding". Acta Paul Enfermagem 2002; 15:17-26.

Submitted on 11/May/2004

Final version resubmitted on 20/Aug/2004

Approved on 24/Aug/2004 